\title{
Value of Blood Cultures in the Management of Children Hospitalized with Community-Acquired Pneumonia
}

Ahmed S. Youssef ${ }^{1}$, Mina Fanous ${ }^{1}$, Faisal J Siddiqui ${ }^{2}$, Jorge Estrada ${ }^{3}$, Valeriy Chorny ${ }^{4}$, Melvyn Braiman 1 , Erick F. Mayer ${ }^{1}$

1. Pediatrics, State University of New York Downstate Medical Center, New York, USA 2. Neonatology, State University of New York Downstate Medical Center, New York, USA 3. Pediatrics, Kings County Hospital, New York, USA 4. Pediatrics, New York University School of Medicine, New York, USA

Corresponding author: Ahmed S. Youssef, ahmedyoussef82@hotmail.com

\section{Abstract \\ Background and objectives}

Current guidelines for the management of community-acquired pneumonia (CAP) in children recommend obtaining a blood culture for children with moderate to severe pneumonia; yet, there is no guidance to assess the severity of the disease. Thus, a blood culture is obtained for the majority of children admitted with CAP, regardless of the severity of their symptoms. The study was designed to investigate and identify the prevalence of bacteremia in pediatric patients hospitalized with CAP and to evaluate the clinical and laboratory variables associated with bacteremia.

\section{Methods}

We conducted a medical record review of children aged from two months to 18 years diagnosed with CAP between January 1, 2013, and December 31, 2017, at our two urban tertiary centers. We used binary logistic regression analysis and chi-square tests to look at factors associated with blood culture positivity.

\section{Results}

A total of 464 patients were admitted with CAP. Blood cultures were obtained in 357 (76.9\%) patients; 23 patients had repeated cultures. Fifteen patients had positive cultures: 5/380 (1.3\%) were considered true positive results and 10/380 (2.6\%) were considered contaminants. Intensive care unit (ICU) admission (OR 5.6 with $95 \%$ CI $(1-31), p<0.03)$, toxic appearance (OR 12.8 with $95 \%$ CI $(1.3-125), p<0.01)$, and significantly elevated C-reactive protein (CRP) $(>300 \mathrm{mg} / \mathrm{L}(\mathrm{p}<0.01)$ were associated with bacteremia.

\section{Conclusion}

Received 04/23/2020

Review began 05/02/2020 Review ended 05/19/2020 Published 05/21/2020

\section{(c) Copyright 2020}

Youssef et al. This is an open access article distributed under the terms of the Creative Commons Attribution License CC-BY 4.0., which permits unrestricted use, distribution, and reproduction in any medium, provided the original author and source are credited.
The prevalence of bacteremia among children admitted for CAP is low. The use of routine blood cultures should be reserved for children with moderate to severe pneumonia. Further studies are required to better risk-stratify children with CAP.

Categories: Pediatrics, Infectious Disease

Keywords: pneumonia, community acquired pneumonia, blood culture

\section{Introduction}

Community-acquired pneumonia (CAP) is one of the main causes of hospitalization of children in the United States, with an annual estimated cost exceeding one billion dollars [1-2]. A recent prospective multicenter study conducted by the Centers for Disease Control and Prevention (CDC) reported that the annual incidence of hospitalization for CAP is 15.7 cases per 10,000 children from January 1, 2010, to June 30, $2012[3]$.

Viruses are by far the most common cause of CAP while bacteria account for only $15 \%$ of cases [3]. After the introduction of the vaccines against Streptococcus pneumoniae and Haemophilus influenza type B, the rates of CAP secondary to these invasive bacterial infections have decreased from $7.7 \%$ to $4 \%$ [4-6].

National guidelines for the management of infants and children with CAP, established in 2011 by the Infectious Diseases Society of America (IDSA), recommend "only obtaining blood culture in children with moderate and severe CAP" [7]. This statement, as mentioned in the guideline, fails to accurately define what would be considered "moderate to severe CAP." Past studies have reported a wide range in the prevalence of bacteremia in CAP $(0.8 \%-17.4 \%)$ [8-13]. 
A drawback of routine cultures is a high proportion of blood culture contamination, ranging from $0.7 \%$ to 8.1\% [14-21]. This results in prolonged hospital stay with subsequent increased cost [18-19]. Blood culture results may influence the management in only $2.2 \%$ of the cases [22-24].

A meta-analysis published in 2015 on the role of blood culture in pediatric CAP found that studies focusing on patients with severe CAP had a higher prevalence of bacteremia when compared to studies that included non-severe CAP. Validated clinical prediction rules or stratification criteria to define or categorize the severity of pediatric CAP are not available [14]. In adults, a six-point scoring system based on the presence of confusion, uremia, respiratory rate, blood pressure, and age $\geqslant 65$ years (CURB-65 (confusion, urea, respiratory rate, blood pressure, and 65 years of age or older) score) is widely adopted to define severe pneumonia [25-27]. Few studies have attempted to describe the correlation of clinical or radiological parameters like toxic appearance or presence of effusion with bacteremia secondary to CAP in children [28].

The main study objective was to identify the prevalence of bacteremia in pediatric patients hospitalized with CAP in two tertiary-level hospitals. Secondary objectives included: (1) to determine the prevalence of falsepositive blood cultures, (2) to identify the microbiology and susceptibility patterns of true positive blood cultures, (3) to identify the clinical and laboratory variables associated with bacteremia in patients hospitalized with CAP, and (4) to determine the impact of blood culture results on antimicrobial therapy and length of hospital stay.

\section{Materials And Methods}

This is a medical record review of all patients admitted to New York City (NYC) Health and Hospitals/Kings County Hospital (KCH) and State University of New York, Downstate Medical Center (DMC) with a diagnosis of community-acquired pneumonia between January 1, 2013, and December 31, 2017. Both centers are tertiary-level hospitals located in Brooklyn, New York. The Institutional Review Board at KCH and DMC approved the study protocol.

We included children and adolescents aged two months to 18 years of age. Subjects were identified according to International Classification of Diseases, Ninth Revision (ICD-9) (480-488.1, 510-511, 513, Jan 1 2013-Sept 30 2015) and ICD-10 (J10-J18.9, Oct 1 2015- Dec 31 2017) codes for pneumonia. We excluded children and adolescents with a diagnosis of hospital-acquired pneumonia, defined as pneumonia diagnosed more than 48 hours from admission or less than two weeks after hospital discharge, as well as children living in chronic care facilities.

Charts were manually reviewed to obtain demographic, clinical, and laboratory data, which included relevant past medical history (previous history of pneumonia, chronic lung disease, asthma, immunodeficiency, sickle cell disease, cerebral palsy), recent use of antibiotics (defined as any patient who self-reported antibiotics use five days before hospitalization ), vaccination status (including influenza vaccine in the last season ), vital signs, general appearance, respiratory examination findings, relevant laboratory results (white blood cell count, neutrophil count, C-reactive protein), imaging studies (chest Xray, ultrasound, tomography), blood culture (obtained in the first 48 hours upon admission), as well as results of other microbial testing, including nasopharyngeal aspirate and pleural fluid analysis (cell count, $\mathrm{pH}$, protein, glucose, lactate dehydrogenase (LDH), culture). Complications encountered during the hospital course included admission or transfer to the pediatric intensive care unit, supplemental oxygen requirement, and ventilatory support. Length of stay was also recorded.

The distinction between true-positive vs. contaminated blood cultures was determined by the primary team taking care of the patient and later reviewed by two of the authors (AY and EFM).

\section{Results}

We collected data from 464 children. The median age was three years (IQR 2-6) and $51.9 \%$ were female. A total of $162(34.9 \%)$ had no significant past medical history and 446 (96\%) were up-to-date on their immunizations, as shown in Table 1 . Table 1 outlines the demographic and clinical characteristics of our population.

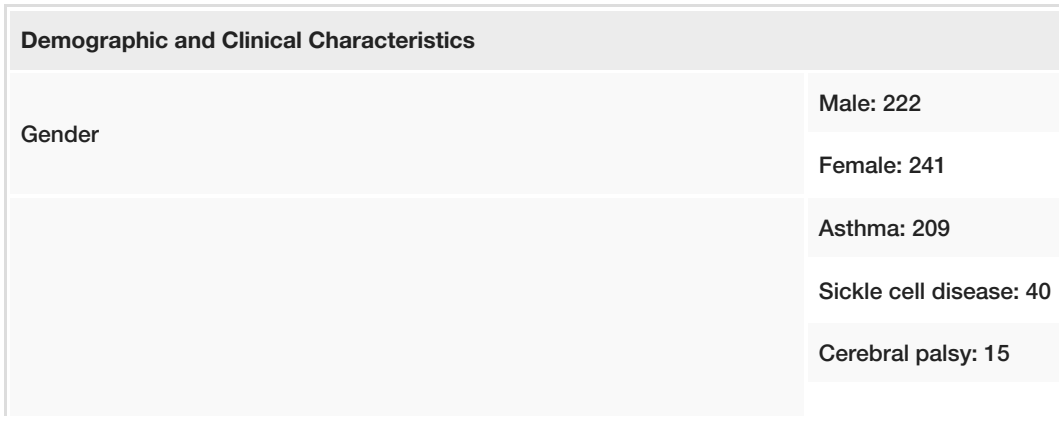




\section{Cureus}

\begin{tabular}{|c|c|}
\hline \multirow{6}{*}{ Medical history } & Immunodeficiency: 3 \\
\hline & Seizures disorder: 6 \\
\hline & Prematurity: 6 \\
\hline & SMA-1: 2 \\
\hline & Others: 16 \\
\hline & No significant PMH: 162 \\
\hline \multirow{3}{*}{ Vaccination } & PCV: 446 \\
\hline & HiB: 446 \\
\hline & Influenza: 285 \\
\hline \multirow{6}{*}{ Received antibiotics prior to admission } & Total: 64 \\
\hline & Amoxicillin: 41 \\
\hline & Macrolides: 11 \\
\hline & Cephalosporins: 7 \\
\hline & Penicillin: 4 \\
\hline & Bacterium: 1 \\
\hline \multirow{5}{*}{ Clinical examination } & Fever: 270 \\
\hline & Crackles: 142 \\
\hline & Wheezes: 175 \\
\hline & Retractions: 208 \\
\hline & Decreased air entry: 140 \\
\hline \multirow{2}{*}{ PICU admission } & Directly admitted from ER: 108 \\
\hline & Transferred from the regular ward: 16 \\
\hline \multirow{3}{*}{ Respiratory support } & Oxygen by nasal cannula: 134 \\
\hline & NIV 2: 60 \\
\hline & Intubation: 8 \\
\hline \multirow{5}{*}{ Radiographic findings } & Focal consolidation: 311 \\
\hline & Perihilar opacity: 76 \\
\hline & Atelectasis effusion /necrotizing: 18 \\
\hline & Normal: 19 \\
\hline & No chest X-ray: 40 \\
\hline \multirow{10}{*}{ WBC $10^{3} / \mu \mathrm{L} ;$ CRP mg/L } & $<15$ 000: 361 \\
\hline & >15 000: 103 \\
\hline & $<5: 16$ \\
\hline & 5-10: 6 \\
\hline & 10-50: 33 \\
\hline & 50-100: 18 \\
\hline & 100-200: 24 \\
\hline & 200-300: 9 \\
\hline & $>300: 3$ \\
\hline & Ampicillin: 178 \\
\hline
\end{tabular}




\section{Cureus}

TABLE 1: Demographic and clinical characteristics of children admitted with CAP

CAP: community-acquired pneumonia; SMA-1: spinal muscular atrophy; PMH: past medical history; PCV: Pneumococcal vaccine; HiB: Haemophilus influenzae type b; ER: emergency room; NIV: noninvasive ventilation

A total of 380 blood cultures were obtained, including 23 patients who had repeated blood cultures. Fifteen (3.9\%) cultures were positive for bacterial growth; five (1.3\%) were considered true positives while the other 10 (2.6\%) were treated as contaminants. The prevalence of bacteremia was $1.3 \%$ in those with blood cultures and $1.0 \%$ in all patients admitted with CAP (Table 2). Except for one patient who had human immunodeficiency virus (HIV) with low cluster of differentiation 4 (CD4) count, none of our bacteremic patients had immunodeficiency, indwelling central line, or sickle cell disease; however, two of them had a history of asthma and prematurity. Out of the five cases of bacteremia, three were caused by S. pneumoniae, one caused by methicillin-resistant, Staphylococcus aureus, and one by Enterococcus avium. 


\section{Cureus}

\begin{tabular}{|c|c|c|c|c|c|c|c|c|c|c|}
\hline No & Age & PMH & Cultures & Hospital course & Toxic & ICU & $\begin{array}{l}\text { WBC } \\
10^{3} / \mathrm{uL}\end{array}$ & $\begin{array}{l}\text { CRP } \\
\mathrm{mg} / \mathrm{L}\end{array}$ & CXR & Antibiotics \\
\hline 1 & $\begin{array}{l}18 \\
\text { years }\end{array}$ & $\begin{array}{l}\text { Congenital HIV } \\
\text { AIDS (viral load } \\
6,270,000, \text { CD4 } \\
2.59, \text { noncompliant } \\
\text { with HAART } 1 \text { and } \\
\text { azithromycin) }\end{array}$ & $\begin{array}{l}\text { Blood culture: } \\
\text { MRSA. Tracheal } \\
\text { aspirate Culture: } \\
\text { MRSA. Sputum } \\
\text { Culture: candida } \\
\text { albicans }\end{array}$ & $\begin{array}{l}\text { ARDS+septic } \\
\text { shock } 2\end{array}$ & Yes & $\begin{array}{l}\text { Direct } \\
\text { admission }\end{array}$ & 3.24 & N/A & $\begin{array}{l}\text { Cavitary } \\
\text { lesion }\end{array}$ & $\begin{array}{l}\text { Initial:- } \\
\text { vancomycin, } \\
\text { piperacillin/ } \\
\text { tazobactam, } \\
\text { and } \\
\text { azithromycin. } \\
\text { Final: -the } \\
\text { patient was } \\
\text { transferred } \\
\text { to another } \\
\text { hospital }\end{array}$ \\
\hline 2 & $\begin{array}{l}5 \\
\text { months }\end{array}$ & $\begin{array}{l}\text { Preterm } 34 \text { weeks } \\
\text { NICU for } 1 \text { month. } \\
\text { No Hx of CLD } 3 \text {. }\end{array}$ & $\begin{array}{l}\text { Blood culture: } \\
\text { Enterococcus } \\
\text { avium sensitive to } \\
\text { Ampicillin. }\end{array}$ & $\begin{array}{l}\text { Needed CPAP } 4 \text {, } \\
\text { positive blood } \\
\text { culture treated as } \\
\text { true infection }\end{array}$ & Yes & $\begin{array}{l}\text { Direct } \\
\text { admission }\end{array}$ & 10.2 & 104 & $\begin{array}{l}\text { Mild pleural } \\
\text { effusion. Did } \\
\text { not need } \\
\text { tapping }\end{array}$ & $\begin{array}{l}\text { Initial :- } \\
\text { vancomycin, } \\
\text { ceftriaxone, } \\
\text { azithromycin. } \\
\text { Final: - } \\
\text { ampicillin. }\end{array}$ \\
\hline 3 & 6 years & $\begin{array}{l}\text { Moderate } \\
\text { persistent asthma }\end{array}$ & $\begin{array}{l}\text { Blood culture: } \\
\text { Streptococcus } \\
\text { pneumoniae }\end{array}$ & $\begin{array}{l}\text { Improvement In } \\
\text { the first } 24 \text { hours. } \\
\text {-But delay in } \\
\text { discharge waiting } \\
\text { for second } \\
\text { culture results }\end{array}$ & No & No & 15.3 & N/A & $\begin{array}{l}\text { Focal } \\
\text { consolidation }\end{array}$ & $\begin{array}{l}\text { Initial: - } \\
\text { ampicillin. } \\
\text { Final: - } \\
\text { ampicillin }\end{array}$ \\
\hline 4 & 8 years & None & $\begin{array}{l}\text { Blood culture: } \\
\text { Streptococcus } \\
\text { pneumoniae }\end{array}$ & $\begin{array}{l}\text { Improvement in } \\
\text { the first } 24 \text { hours. } \\
\text { But unnecessary } \\
\text { antibiotic } \\
\text { upgrade and } \\
\text { delay in } \\
\text { discharge }\end{array}$ & No & No & 30 & N/A & $\begin{array}{l}\text { Focal } \\
\text { consolidation }\end{array}$ & $\begin{array}{l}\text { Initial: - } \\
\text { ampicillin } \\
\text { and } \\
\text { azithromycin; } \\
\text { later } \\
\text { changed to } \\
\text { ceftriaxone } \\
\text { based on } \\
\text { culture } \\
\text { results. Final: } \\
\text { - amoxicillin }\end{array}$ \\
\hline 5 & 3 years & None & $\begin{array}{l}\text { Blood culture: } \\
\text { Streptococcus } \\
\text { Pneumoniae. } \\
\text { Pleural fluid } \\
\text { culture: no } \\
\text { growth. }\end{array}$ & $\begin{array}{l}\text { Needed BIPAP 5, } \\
\text { and right-side } \\
\text { decortication }\end{array}$ & No & $\begin{array}{l}\text { Transferred } \\
\text { on the } \\
\text { second day } \\
\text { of } \\
\text { admission }\end{array}$ & 17 & 321 & $\begin{array}{l}\text { Large pleural } \\
\text { effusion }\end{array}$ & $\begin{array}{l}\text { Initial } \\
\text { ampicillin; } \\
\text { later } \\
\text { changed to } \\
\text { ceftriaxone } \\
\text { and } \\
\text { vancomycin. } \\
\text { Final: - } \\
\text { amoxicillin }\end{array}$ \\
\hline
\end{tabular}

TABLE 2: Demographic, clinical, laboratory, and radiological characteristics of patients with

\section{bacteremia}

HIV: human immunodeficiency syndrome; AIDS: acquired immunodeficiency syndrome; CD4: cluster of differentiation 4; HAART: highly active antiretroviral therapy; MRSA: methicillin-resistant Staphylococcus aureus; ARDS: acute respiratory distress syndrome; NICU: neonatal intensive care unit; CLD: chronic liver disease; CPAP: continuous positive airway pressure; BIPAP: bilevel positive airway pressure 
Two patients who were admitted to the inpatient unit were started on ampicillin and continued to show improvement on the same antibiotic. We found a significant association between PICU admission (OR 5.6 and 95\% CI (1.0-31), p<0.03) and ill appearance on presentation (OR 12.8 and 95\% CI (1.3-125), p<0.01) with a true-positive blood culture.

Ten out of 15 positive cultures (67\%) were contaminated: three of the contaminant cultures grew Streptococcus viridans, two grew Staphylococcus hominis, one culture grew both Acinetobacter baumannii and Corynebacterium striatum while the remaining grew Staphylococcus haemolyticus, Staphylococcus simulans, and Rothia spp. Fifty percent of the false-positive cultures were repeated. (Table 3).

\begin{tabular}{|c|c|c|c|c|c|c|c|c|c|c|}
\hline No. & Age & Vaccination & PMH & ICU & $\begin{array}{l}\text { WBC } \\
10^{3} /^{27} \text { ul }\end{array}$ & CXR & $\begin{array}{l}\text { CRP } \\
\mathrm{mg} / \mathrm{L}\end{array}$ & Hospital course & Cultures & Antibiotics \\
\hline 1 & $\begin{array}{l}20 \\
\text { months }\end{array}$ & Yes & None & No & 22.5 & $\mathrm{~N}$ & No & $\begin{array}{l}\text { Hospital stay: } 21 \\
\text { hours. }\end{array}$ & $\begin{array}{l}\text { Blood culture: Staph } \\
\text { simulans }\end{array}$ & $\begin{array}{l}\text { Initial: Amoxicillin for } \\
1 \text { day. Final: } \\
\text { Amoxicillin } 10 \text { days } \\
\text { as an outpatient }\end{array}$ \\
\hline 2 & $\begin{array}{l}19 \\
\text { months }\end{array}$ & No & None & No & 11.8 & $\mathrm{~N}$ & No & $\begin{array}{l}\text { Hospital stay } 50 \\
\text { hours }\end{array}$ & $\begin{array}{l}\text { Blood culture: Staph } \\
\text { Hominis }\end{array}$ & $\begin{array}{l}\text { Initial: Ceftriaxone } \\
\text { for } 1 \text { day. Final: } \\
\text { Amoxicillin for } 10 \\
\text { days as an } \\
\text { outpatient }\end{array}$ \\
\hline 3 & 3 years & Yes & None & No & 8.1 & $\mathbf{N}$ & No & $\begin{array}{l}\text { Hospital stay } 24 \\
\text { hours }\end{array}$ & $\begin{array}{l}\text { Blood culture: Strep } \\
\text { Viridans }\end{array}$ & $\begin{array}{l}\text { Ampicillin one dose } \\
\text { in the ED }\end{array}$ \\
\hline 4 & 6 years & Yes & $\begin{array}{l}\text { Mild } \\
\text { persistent } \\
\text { asthma }\end{array}$ & No & 17.1 & $\mathrm{~N}$ & No & $\begin{array}{l}\text { Hospital stay } 1 \text { day } \\
\text { and } 21 \text { hours }\end{array}$ & $\begin{array}{l}\text { Blood culture: Staph } \\
\text { Hominis }\end{array}$ & $\begin{array}{l}\text { Initial: Ampicillin one } \\
\text { dose in the ED. Final: } \\
\text { Amoxicillin for } 10 \\
\text { days as an } \\
\text { outpatient }\end{array}$ \\
\hline 5 & $\begin{array}{l}4 \\
\text { months }\end{array}$ & No & None & No & 27.1 & 37.3 & No & $\begin{array}{l}\text { days, } 15 \text { hours } \\
\text { Inpatient team } \\
\text { impression that } \\
\text { blood culture is } \\
\text { contaminant }\end{array}$ & $\begin{array}{l}\text { Blood culture: Strep } \\
\text { Viridans Urine } \\
\text { culture: } \\
\text { Pseudomonas. }\end{array}$ & $\begin{array}{l}\text { Initial: ceftriaxone for } \\
2 \text { days. Final: } \\
\text { cephalexin for } 10 \\
\text { Days as an } \\
\text { outpatient. }\end{array}$ \\
\hline 6 & 4 years & Yes & None & No & 9.9 & $\mathbf{N}$ & No & $\begin{array}{l}\text { Hospital stay } 1 \text { day, } \\
5 \text { hours }\end{array}$ & $\begin{array}{l}\text { Blood culture: } \\
\text { Rothia Dentocariosa }\end{array}$ & $\begin{array}{l}\text { Ceftriaxone one } \\
\text { dose in the ED }\end{array}$ \\
\hline 7 & 2 years & Yes & None & Yes & 7 & $\mathrm{~N}$ & No & $\begin{array}{l}\text { inpatient team } \\
\text { impression it is a } \\
\text { contaminant, but } \\
\text { continued } \\
\text { antibiotics. Normal } \\
\text { Echo. Total hospital } \\
\text { stay: } 3 \text { days, } 13 \\
\text { hours. }\end{array}$ & $\begin{array}{l}\text { Blood culture: Strep } \\
\text { viridans }\end{array}$ & $\begin{array}{l}\text { Initial: Ceftriaxone } \\
\text { for } 1 \text { day then } \\
\text { ampicillin for } 2 \text { days. } \\
\text { Final: amoxicillin for } \\
7 \text { as an outpatient }\end{array}$ \\
\hline 8 & 2 years & No & $\begin{array}{l}\text { Williams } \\
\text { syndrome. } \\
\text { Mild } \\
\text { persistent } \\
\text { asthma. Has } \\
\text { tracheostomy }\end{array}$ & Yes & 15 & 7.7 & No & $\begin{array}{l}\text { treated for the } \\
\text { Serratia marcescens } \\
\text { infection. Blood } \\
\text { culture considered a } \\
\text { contaminant. Total } \\
\text { hospital stay: } 4 \\
\text { days, } 21 \text { hours }\end{array}$ & $\begin{array}{l}\text { Blood culture: } \\
\text { Acinetobacter } \\
\text { baumanni+ } \\
\text { Corynebacterium } \\
\text { Striatum. Tracheal } \\
\text { aspirate culture: } \\
\text { Serratia marcescens } \\
\text { RVP1: RSV }\end{array}$ & $\begin{array}{l}\text { Ceftriaxone for } 3 \\
\text { days. Then cefixime } \\
\text { for } 2 \text { days }\end{array}$ \\
\hline 9 & $\begin{array}{l}16 \\
\text { years }\end{array}$ & No & $\begin{array}{l}\text { Cerebral } \\
\text { palsy G-tube. } \\
\text { Scoliosis }\end{array}$ & Yes & 11.2 & $\mathrm{~N}$ & No & $\begin{array}{l}\text { Treated as } \\
\text { Aspiration } \\
\text { pneumonia. } 1 \text { day in } \\
\text { PICU, NIV not } \\
\text { needed. Total } \\
\text { hospital stay: } 4 \text { days, }\end{array}$ & $\begin{array}{l}\text { Blood culture staph } \\
\text { capitis }\end{array}$ & $\begin{array}{l}\text { Ceftriaxone + } \\
\text { Ampicillin/Sulbactam } \\
\text { for } 1 \text { day. Then } \\
\text { Amoxicillin+ } \\
\text { clavulanic acid for } 4 \\
\text { days }\end{array}$ \\
\hline
\end{tabular}




\section{Cureus}

\begin{tabular}{|c|c|c|c|c|c|c|c|c|c|c|}
\hline & & & & & & & & 1 hour. & & \\
\hline 10 & 7 years & Yes & $\begin{array}{l}\text { Intermittent } \\
\text { asthma }\end{array}$ & No & 5.7 & $\mathrm{~N}$ & No & $\begin{array}{l}\text { Hospital stay: } 7 \\
\text { hours. }\end{array}$ & $\begin{array}{l}\text { Blood culture: Staph } \\
\text { haemolyticus }\end{array}$ & $\begin{array}{l}\text { Ampicillin one dose } \\
\text { in the ED }\end{array}$ \\
\hline
\end{tabular}

TABLE 3: Demographic, clinical, laboratory, and radiological characteristics of patients with falsepositive (contaminated) blood cultures

WBC: white blood cell; CXR: chest X-ray; CRP: C-reactive protein; ED: emergency department

Finally, in regard to the radiological and laboratory investigations. Of 19 (4\%) patients with evidence of effusion or necrotizing pneumonia on chest radiographs, three out of the 19 patients had positive blood cultures; and out of these three, only one patient underwent pleural fluid tapping. Two additional patients who underwent pleural tapping had negative blood cultures, and none of these three patients who undergone tapping had positive pleural fluid cultures. The radiographic evidence of effusion or necrotizing pneumonia was associated with bacteremia $(\mathrm{P}<0.11)$ while the binary logistics regression analysis showed that significantly elevated CRP $(>300 \mathrm{mg} / \mathrm{L})$ was associated with a true-positive blood culture $(\mathrm{p}<0.01)$.

\section{Discussion}

Bacteremia is an unusual complication of CAP in hospitalized children. Our study suggests that approximately $1 \%$ of admitted children with CAP are bacteremic. Penicillin-susceptible S. pneumoniae was the most common isolated organism (60\%), which is consistent with recently published studies [15]. Patients with bacteremia mostly had co-morbid conditions, were ill-appearing, or were admitted to the PICU. Our findings are consistent with current IDSA guidelines, which suggest that only children with moderate to severe CAP will benefit from obtaining a blood culture on admission.

Unlike some reports, we did not find a correlation between the radiological findings of effusion or necrotizing pneumonia and a truly positive blood culture. Heine et al. found that five out of 155 children who were admitted with pneumonia to the Children's Hospital at the Medical University of South Carolina or discharged from the ED were bacteremic; all five cases had parapneumonic effusions [28]. Heine et al. found that five out of 155 children who were admitted to the Children's Hospital at the Medical University of South Carolina with pneumonia were bacteremic and all of them had parapneumonic effusions. Similarly, Kwon et al. found a low prevalence of bacteremia in 2705 previously healthy children and adolescents. Of 2705 , only three children $(0.11 \%)$ had true-positive results, and all of them had pneumonia complicated with pleural effusion [29]. Another study by Myers et al. reported that children who required pleural drainage procedure or had a distant site infection had higher rates of bacteremia $-21 \%$ and $75 \%$, respectively [11].

Toxic appearance and admission or transfer to the PICU were associated with bacteremia. This is consistent with prior reports from Heine et al., where four out of five children with CAP complicated by bacteremia required ICU care.

The impact in the management of the blood culture results was limited in our study. Two patients were admitted directly to the ICU while a third one was transferred from the inpatient unit after clinical deterioration. The results from the blood culture allowed for accurate diagnosis in all of them and appropriate antibiotic de-escalation at least in two of the patients.

For the two other patients admitted to the inpatient unit, these results led to a therapeutic dilemma with subsequent prolongation of hospital stay for both of them and unnecessary broadening of antibiotics for one of them, even though the reported organism was penicillin-susceptible S. pneumoniae.

The prevalence of blood culture contaminants in this study was $2.6 \%$, which is similar to prior reports [28]. Furthermore, a positive blood culture was twice more likely to be a contaminant than a true pathogen. Despite the high likelihood of reported growth in blood culture to be a contaminant, determining the possibility of true bacteremia is still challenging for physicians and impacts negatively on patient care. In this study, five of the 10 patients with false-positive cultures had repeated cultures, even though the treating physician's impression was in favor of a contaminant organism.

This study has several limitations. Our research is a retrospective chart review that is more prone to chart abstraction biases, especially personal data such as ill appearance. This study was done in our two urban academic medical centers and its results may not be generalizable to other institutions. Finally, we do not have data on whether children discharged from our two facilities may have been readmitted to other hospitals.

\section{Conclusions}


The rate of positive blood cultures in children admitted with CAP is low, and its impact on clinical management is limited. Children that were ill-appearing, admitted to the intensive care unit, or with significantly elevated CRP levels were more likely to have bacteremia secondary to CAP. The current recommendation of obtaining a blood culture for children with moderate to severe CAP, although correct, needs to be clarified. Further studies are needed to better risk-stratify children with CAP, thus providing a targeted approach for obtaining blood cultures, standardizing management, and potentially reducing the cost and length of hospital stay.

\section{Additional Information \\ Disclosures}

Human subjects: Consent was obtained by all participants in this study. SUNY Downstate Medical Center issued approval 1171456-2. Animal subjects: All authors have confirmed that this study did not involve animal subjects or tissue. Conflicts of interest: In compliance with the ICMJE uniform disclosure form, all authors declare the following: Payment/services info: All authors have declared that no financial support was received from any organization for the submitted work. Financial relationships: All authors have declared that they have no financial relationships at present or within the previous three years with any organizations that might have an interest in the submitted work. Other relationships: All authors have declared that there are no other relationships or activities that could appear to have influenced the submitted work.

\section{References}

1. Overview of hospital stays for children in the United States, 2012. HCUP statistical brief \#187 . (2014). https://www.hcup-us.ahrq.gov/reports/statbriefs/sb187-Hospital-Stays-Children-2012.jsp.

2. Hospital stays for children, 2009. HCUP statistical brief \#118 . (2011). https://www.hcupus.ahrq.gov/reports/statbriefs/sb118.pdf.

3. Jain S, Williams DJ, Arnold SR, et al.: CDC EPIC Study Team. Community acquired pneumonia requiring hospitalization among U.S. children. N Engl J Med. 2015, 372:835-845. 10.1056/NEJMoa1500245

4. Zhou F, Kyaw MH, Shefer A, Winston CA, Nuorti JP: Health care utilization for pneumonia in young children after routine pneumococcal conjugate vaccine use in the United States. Arch Pediatr Adolesc Med. 2007, 161:1162-1168. 10.1001/archpedi.161.12.1162

5. Nelson JC, Jackson M, Yu O, et al.: Impact of the introduction of pneumococcal conjugate vaccine on rates of community acquired pneumonia in children and adults. Vaccine. 2008, 26:4947-4954. 10.1016/j.vaccine.2008.07.016

6. Grijalva CG, Nuorti JP, Arbogast PG, Martin SW, Edwards KM, Griffin MR: Decline in pneumonia admissions after routine childhood immunization with pneumococcal conjugate vaccine in the USA: a time-series analysis. Lancet. 2007, 369:1179-86. 10.1016/S0140-6736(07)60564-9

7. Bradley JS, Byington CL, Shah SS, et al.: The management of community-acquired pneumonia in infants and children older than 3 months of age: clinical practice guidelines by the Pediatric Infectious Diseases Society and the Infectious Diseases Society of America. Clin Infect Dis. 2011, 53:25-76. 10.1093/cid/cir531

8. Bonadio WA: Bacteremia in febrile children with lobar pneumonia and leukocytosis . Pediatr Emerg Care. 1988, 4:241-242. 10.1097/00006565-198812000-00002

9. Shah SS, Dugan MH, Bell LM, et al.: Blood cultures in the emergency department evaluation of childhood pneumonia. Pediatr Infect Dis J. 2011, 30:475-479. 10.1016/j.jemermed.2011.08.005

10. Davis TR, Evans HR, Murtas J, Weisman A, Francis JL, Khan A: Utility of blood cultures in children admitted to hospital with community-acquired pneumonia. J Paediatr Child Health. 2017, 53:232-236. 10.1111/jpc. 13376

11. Myers AL, Hall M, Williams DJ, et al.: Prevalence of bacteremia in hospitalized pediatric patients with community-acquired pneumonia. Pediatr Infect Dis J. 2013, 32:736-740. 10.1097/INF.0b013e318290bf63

12. McCulloh RJ, Koster MP, Yin DE, et al.: Evaluating the use of blood cultures in the management of children hospitalized for community-acquired pneumonia. PLoS One. 2015, 10:e0117462.

10.1371/journal.pone.0117462

13. Esposito S, Marchese A, Tozzi AE, et al.: Bacteremic pneumococcal community-acquired pneumonia in children less than 5 years of age in Italy. Pediatr Infect Dis J. 2012, 31:705-710. 10.1097/INF.0b013e31825384ae

14. Tam PYI, Bernstein E, Ma X, Ferrieri P: Blood culture in evaluation of pediatric community-acquired pneumonia: a systematic review and meta-analysis. Hosp Pediatr. 2015, 5:324-336. 10.1542/hpeds.20140138

15. Kennedy M, Bates DW, Wright SB, Ruiz R, Wolfe RE, Shapiro NI: Do emergency department blood cultures change practice in patients with pneumonia?. Ann Emerg Med. 2005, 46:393-400. 10.1016/j.annemergmed.2005.05.025

16. Corbo J, Friedman B, Bijur P, Gallagher EJ: Limited usefulness of initial blood cultures in community acquired pneumonia. Emerg Med J. 2004, 21:446-448.

17. Zwang O, Albert RK: Analysis of strategies to improve cost effectiveness of blood cultures . J Hosp Med. 2006, 1:272-276. 10.1002/jhm.115

18. Bates DW, Goldman L, Lee TH: Contaminant blood cultures and resource utilization. The true consequences of false-positive results. JAMA. 1991, 265:365-369. 10.1001/jama.1991.03460030071031

19. Surdulescu S, Utamsingh D, Shekar R: Phlebotomy teams reduce blood-culture contamination rate and save money. Clin Perform Qual Health Care. 1998, 6:60-62.

20. Sard B, Bailey MC, Vinci R: An analysis of pediatric blood cultures in the postpneumococcal conjugate vaccine era in a community hospital emergency department. Pediatr Emerg Care. 2006, 22:295-300. 


\section{Cureus}

10.1097/01.pec.0000215137.51909.16

21. Souvenir D, Anderson DE Jr, Palpant S, et al.: Blood cultures positive for coagulase negative staphylococci: antisepsis, pseudobacteremia, and therapy of patients. J Clin Microbiol. 1998, 36:1923-1926.

22. Campbell SG, Marrie TJ, Anstey R, Ackroyd- Stolarz S, Dickinson G: Utility of blood cultures in the management of adults with community acquired pneumonia discharged from the emergency department. Emerg Med J. 2003, 20:521-523. 10.1136/emj.20.6.521

23. Abe T, Tokuda Y, Ishimatsu S, Birrer RB: Usefulness of initial blood cultures in patients admitted with pneumonia from an emergency department in Japan. J Infect Chemother. 2009, 15:180-186.

24. Ramanujam P, Rathlev NK: Blood cultures do not change management in hospitalized patients with community-acquired pneumonia. Acad Emerg Med. 2006, 13:740-745. 10.1197/j.aem.2006.03.554

25. Fine MJ, Auble TE, Yealy DM, et al.: A prediction rule to identify low-risk patients with community-acquired pneumonia. N Engl J Med. 1997, 336:243-250. 10.1056/NEJM199701233360402

26. Chalmers JD, Singanayagam A, Akram AR, Choudhury G, Mandal P, Hill AT: Safety and efficacy of CURB65guided antibiotic therapy in community-acquired pneumonia. J Antimicrob Chemother. 2010, 66:416-423. $10.1093 / \mathrm{jac} / \mathrm{dkq} 426$

27. Lim WS, van der Eerden MM, Laing R, et al.: Defining community acquired pneumonia severity on presentation to hospital: an international derivation and validation study. Thorax. 2003, 58:377-382. 10.1136/thorax.58.5.377

28. Heine D, Cochran C, Moore M, Titus MO, Andrews AL: The prevalence of bacteremia in pediatric patients with community-acquired pneumonia: guidelines to reduce the frequency of obtaining blood cultures. Hosp Pediatr. 2013, 3:92-96. 10.1542/hpeds.2012-0050

29. Kwon JH, Kim JH, Lee JY, Kim YJ, Sohn CH, Lim KS, Kim WY: Low utility of blood culture in pediatric community-acquired pneumonia: an observational study on 2705 patients admitted to the emergency department. Medicine (Baltimore). 2017, 96:e7028. 10.1097/MD.0000000000007028 